JURNAL ABDI INSANI UNIVERSITAS MATARAM

Volume 8, Nomor 2, Agustus 2021

Homepage : http://abdiinsani.unram.ac.id. e-ISSN : 2657-0629

\title{
PEMBANGUNAN PROTOTIPE SUMUR RESAPAN DI KAWASAN PERUMAHAN PADAT PENDUDUK KOTA PANGKALPINANG
}

\section{Development Of Infiltration Well Prototype In Solid Population Housing Area Of Pangkalpinang City}

\author{
Roby Hambali $^{\left.i^{*}\right)}$, Yayuk Apriyanti ${ }^{1}$, Irvani ${ }^{2}$ \\ 1Jurusan Teknik Sipil, Fakultas Teknik, Universitas Bangka Belitung, 2Jurusan Teknik \\ Pertambangan, Fakultas Teknik, Universitas Bangka Belitung \\ Kampus Terpadu Universitas Bangka Belitung, Balunijuk, Kecamatan Merawang, \\ Kabupaten Bangka, Provinsi Kepulauan Bangka Belitung
}

Alamat korespondensi: robyhambali@ubb.ac.id

(Tanggal Submission: 28 July 2021, Tanggal Accepted : 19 Agustus 2021)

\begin{abstract}
Kata Kunci : $\quad$ Abstrak :
Perumahan, Pembangunan perumahan secara intensif yang dilakukan di Kota Pangkalpinang Konservasiair, dengan kondisi yang minim ruang terbuka hijau menyebabkan tingginya Drainase limpasan permukaan pada musim hujan, dan berkurangnya pengisian cadangan berwawasan air tanah. Hal tersebut menyebabkan terjadinya bencana banjir. Selain itu, lingkungan, rendahnya pengisian cadangan air tanah juga dapat menyebabkan kekeringan di Sumur resapan musim kemarau. Kegiatan pengabdian kepada masyarakat ini bertujuan untuk menyebarluaskan pengetahun tentang konsep tata kelola air yang baik dengan sistem drainase berwawasan lingkungan. Program ini terdiri dari dua kegiatan utama, yaitu sosialisasi dan pembuatan contoh implementasi teknologi konservasi air. Sosialisasi materi kegiatan dilakukan melalui penyebaran poster, sementara pembuatan contoh implementasi teknologi konservasi air dilakukan dengan pembangunan prototipe sumur resapan. Capaian telah didapatkan melalui kegiatan ini antara lain meningkatnya pengetahuan masyarakat setempat tentang konsep tata kelola air hujan berwawasan lingkungan, serta terbangunnya prototipe sumur resapan di tiga titik dalam Kawasan perumahan sebagai contoh aplikasi teknologi konservasi air hujan. Namun demikian, capaian dalam bentuk partisipasi aktif masyarakat secara langsung belum tercapai, karena adanya pembatasan fisik dalam situasi pandemi Covid-19.
\end{abstract}

Panduan sitasi / Citation guidance (APPA $7^{\text {th }}$ edition) :

Hambali, R., Apriyanti, Y., \& Irvani. (2021). Pembangunan Prototipe Sumur Resapan Di Kawasan Perumahan Padat Penduduk Kota Pangkalpinang. Abdi Insani, 8 (2), 181-192. http://doi.org/10.29303/abdiinsani.v8i2.406 


\section{PENDAHULUAN}

Dalam beberapa tahun terakhir, pembangunan perumahan subsidi (rumah sangat sederhana) sangat masif dilakukan di Kota Pangkalpinang. Pada tahun 2020 tercatat sebanyak 163 kompleks perumahan di Kota Pangkalpinang yang telah dibangun (Anonim, 2020). Dalam satu kompleks perumahan, jumlah unit rumah bervariasi antara 100-300 unit, dengan luasan lantai minimal 36 $\mathrm{m}^{2} /$ unit. Dengan demikian, diperkirakan telah terdapat lebih dari 20 ribu unit rumah tipe 36 yang telah dibangun melalui skema pengembangan rumah subsidi. Konsekuensi dari pembangunan perumahan tersebut adalah berubahnya tutupan lahan bervegetasi menjadi non-vegetasi seluas lebih dari $100 \mathrm{Ha}$ (Hambali, 2020).

Perubahan lahan dengan penutup bervegetasi menjadi tidak bervegetasi dapat berdampak negatif bagi sistem keseimbangan air tanah dan air permukaan. Jika air yang terinfiltrasi (masuk) ke dalam tanah kecil, maka air yang menjadi limpasan permukaan (surface runoff) akan besar, begitu juga sebaliknya. Transformasi hujan menjadi aliran sangat dipengaruhi oleh karakteristik daerah tangkapan airnya (catchment area). Karakteristik daerah tangkapan air tersebut dapat digambarkan melalui sifat alami (natural characteristic) dan sifat anthropogenik. Sifat anthropogenik sendiri dipengaruhi oleh aktivitas manusia dan dapat memberikan kontribusi yang berarti terhadap terjadinya bencana banjir dan kekeringan. Maria \& Lestiana (2014), menunjukkan bahwa perubahan kawasan konservasi menjadi kawasan terbangun telah menurunkan nilai konservasi aktual. Kompleks perumahan di Kota Pangkalpinang umumnya tidak menyediakan ruang terbuka hijau yang cukup. Disisi lain, dengan ketersediaan lahan pribadi yang terbatas, pemilik rumah cenderung memanfaatkan hampir seluruh ruang terbuka yang ada sebagai ruang terbangun yang ditutupi dengan materian kedap air.

Dampak negatif perubahan lahan yang masif di Kota Pangkalpinang ini jelas terlihat dengan meningkatnya frekuensi maupun magnitude kejadian banjir dan kekeringan. Peristiwa banjirpada tanggal 7-9 Februari 2016 tercatat sebagai banjir terbesar dalam tiga dekade terakhir yang pernah terjadi di Kota Pangkalpinang. Sementara itu, Badan Penanggulangan Bencana Daerah (BPBD) Provinsi Bangka Belitung menyatakan bahwa daerah yang terdampak kekeringan di Kota Pangkalpinang pada tahun 2019 seluas 2.097 hektar, dengan jumlah penduduk terdampak 196.154 jiwa (Ferdiansyah, 2019).

Salah satu upaya yang dapat dilakukan dalam mitigasi bencana banjir dan kekeringan adalah dengan mengoptimalkan fungsi konservasi lahan. Konservasi dalam konteks ini ditujukan untuk menjaga keseimbangan antara air permukaan dan air tanah. Salah satu metode sederhana yang dapat diterapkan dalam upaya konservasi air adalah kegiatan pembangunan sumur resapan (Azis et al., 2016; Bunganaen et al., 2016; Fachrurazie et al., 2002). Sumur resapan merupakan bagian dari sistem drainase yang menganut konsep mengeringkan daerah layanan dengan memberi kesempatan dan jalan bagi air hujan yang jatuh di atap atau suatu lahan untuk ditampung dan diresapkan ke dalam tanah.

Belum diterapkannya tata kelola air yang baik pada lingkungan perumahan/permukiman disebabkan oleh minimnya pengetahuan (baik Pengembang maupun warga) tentang cara kerja alami air dalam siklus hidrologi maupun keseimbangan air di alam. Untuk itu, penyebarluasan ilmu pengetahuan tentang konsep dan teknologi konservasi air kepada masyarakat, khususnya semua pihak yang terlibat dalam pembangunan dan pemanfaatan perumahan penting dilakukan. Pelaksanaan kegiatan pengabdian masyarakat yang dilakukan ini bertujuan untuk (1) menyebarluaskan pengetahuan tentang konsep dan teknologi konservasi air pada level rumah tangga; (2) memberikan 
contoh implementasi teknologi konservasi air hujan pada level rumah tangga dengan membangun prototipe sumur resapan; (3) pemberdayaan masyarakat dalam implementasi konservasi air. Melalui program iptek bagi masyarakat (IbM) "Sosialisasi dan Implementasi Prototipe Sumur Resapan Untuk Konservasi Air Kawasan Permukiman di Kota Pangkalpinang" diharapkan masyarakat akan memiliki pengetahuan dan kemampuan dalam usaha penerapan teknologi konservasi air di lingkungan tempat tinggal mereka sendiri.

\section{METODE KEGIATAN}

Indo Griya di Kelurahan Jerambah Gantung dan Indo Residence di Kelurahan Selindung merupakan dua diantara ratusan kompleks perumahan subsidi di Kota Pangkalpinang. Pada umumnya, penggunaan lahan di kompleks perumahan subsidi lebih diprioritaskan pada kuantitas bangunan rumah sebanyak mungkin, sehingga ruang terbuka hijau yang tersisa sangat sedikit. Pada perumahan Indo Griya, terdapat 253 unit rumah pada lahan seluas $4.1 \mathrm{Ha}$, sementara di Indo Residence terdapat 150 unit rumah pada lahan seluas $2.43 \mathrm{Ha}$. Umumnya luas lahan untuk satu unit rumah adalah $72 \mathrm{~m}^{2}$ $(6 \times 12 \mathrm{~m})-96 \mathrm{~m}^{2}$ (8x142 m). Pada awal pembangunan, sekitar 10-15\% luas lahan tiap-tiap unit disediakan sebagai ruang terbuka hijau. Seiring berjalannya waktu (setelah dihuni), hampir seluruh luas unit lahan akan tertutup dengan atap oleh pemilik rumah. Gambar 1 merupakan citra satelit kompleks Indo Griya dan Indo residence yang menunjukkan luas penggunaan lahan perumahan.

Dengan penggunaan lahan yang hampir 100\% kedap air (atap dan paving block) dapat diperkirakan tidak lebih dari $5 \%$ air hujan yang jatuh dalam kawasan perumahan tersebut terserap ke dalam tanah. Hal ini memberikan dampak negatif yang signifikan, baik berupa banjir di musim hujan maupun kekeringan di musim kemarau. Dalam beberapa tahun terakhir, kejadian banjir di sekitar kawasan Indo Griya maupun Indo residence sudah beberapa kali terjadi, meskipun dengan luas dan kedalaman yang belum terlalu besar. Disisi lain, sebagian penghuni perumahan sudah mulai mengeluhkan kesulitan air bersih, khususnya pada musim kemarau.

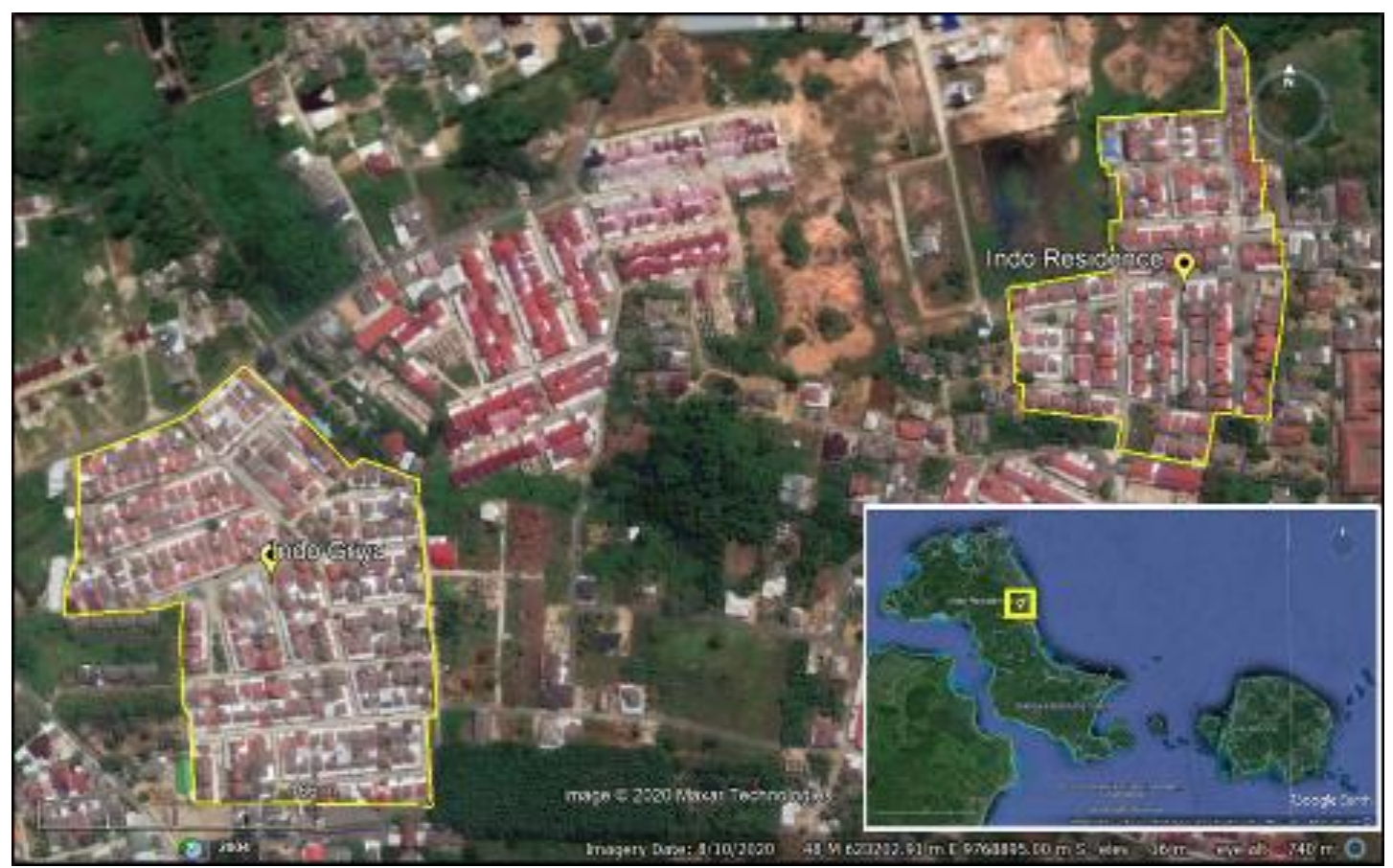

Gambar 1. Peta situasi Perumahan Indo Griya dan Indo Residence 
Berdasarkan pengamatan dan wawancara pendahuluan, dapat dinilai bahwa karakteristik wilayah Perumahan Indo Griya dan Indo residence dapat diterapkan sistem sumur resapan, karena memiliki muka air tanah yang cukup dalam (>3 m) dan jenis tanah porus (tampak visual).

Kegiatan pembuatan protipe sumur resapan ini dilakukan melalui tiga tahapan, yaitu tahapan sosialisasi, pengujian sampel tanah, dan pemasangan sistem sumur resapan. Sosialisasi dimaksudkan untuk memberikan pengetahuan umum kepada masyarakat tentang konsep konservasi air rumah tangga serta metode sumur resapan. Dalam perencanaannya, metode sosialisai yang dipilih adalah metode penyuluhan. Namun, dengan adanya pembatasan fisik akibat Covid-19, maka metode sosialisasi diganti dengan penyebarlusan poster.

Materi sosialisasi dipersiapkan dengan memperhatikan sasaran sosialisasi, yaitu masyarakat umum yang heterogen. Materi sosialisasi disusun sedemikian sehingga mudah dipahami oleh sasaran. Adapun cakupan materi sosialisasi antara lain biodata tim pelaksana kegiatan, konsep dasar siklus hidrologi dan keseimbangan air, dampak pembangunan infrastruktur terhadap lingkungan, prinsip dasar tata kelola air berwawasan lingkungan, sistem drainase berwawasan lingkungan, teknologi konservasi air dengan sumur resapan.

Pengujian sampel tanah diperlukan untuk mengetahui klasifikasi tanah, sehingga dapat ditentukan nilai parameter permeabilitas tanah $(K)$. Permeabilitas tanah adalah kemampuan tanah untuk mengalirkan air. Jenis tanah diklasifikasikan berdasarkan Unified Soil Clasiification System (USCS). Pengujian tanah yang dilakukan adalah analisis saringan (shieve analysis) berdasarkan (SNI 3423, 2008), serta batas konsistensi berdasarkan (SNI 1966, 2008) (batas cair) dan (SNI 1967, 2008) (batas plastis dan indeks plastisitas). Pengambilan sampel tanah dilakukan dengan menggunakan alat bor tangan (hand bor) dengan jumlah satu titik sampel untuk setiap kompleks perumahan. Sampel tanah yang telah diambil kemudian dibawa ke laboratorium untuk dilakukan pengujian. Sampel tanah dikeringkan dalam oven, kemudian dilanjutkan dengan prose penumbukan tanah dengan menggunakan palu karet, lalu dilakukan pengujian analisa saringan. Pengujian analisis saringan (shieve analysis) dilakukan dengan menggunakan satu set alat saringan, mulai dari saringan no 4 (diameter $4.75 \mathrm{~mm}$ ) hingga pan (diameter $0.05 \mathrm{~mm}$ ). Data keluaran analisa saringan yang digunakan adalah persentase tanah yang tertahan dan lolos dari setiap saringan. Pada pengujian batas konsistensi menggunakan alat atterberg untuk batas cair $(L L)$ dan untuk batas plastis $(P L)$ dengan menggelengkan tanah pada pelat kaca. Tanah yang digunakan adalah tanah yang lolos saringan No.40 .

Desain prototipe sumur resapan (perhitungan dimensi dan kapasitas) sumur resapan mengacu pada (SNI 8456, 2017). Berdasarkan (SNI 8456, 2017), persyaratan teknis yang harus dipenuhi adalah sebagai berikut:

a. Sumur resapan air hujan digunakan untuk kedalaman air tanah $>2 \mathrm{~m}$, jika kedalaman air tanah $<2 \mathrm{~m}$, bisa menggunakan parit resapan air hujan.

b. Penampang sumur resapan air hujan berbentuk segi empat atau lingkaran, dimungkinkan untuk bentuk lainnya dengan memperhatikan kemudahan dalam pengerjaan;

c. Ukuran sisi penampang sumur resapan air hujan $80 \mathrm{~cm}$ sampai dengan $100 \mathrm{~cm}$.

d. Struktur tanah yang dapat digunakan harus mempunyai nilai koefisien permeabilitas tanah $>$ $2.0 \mathrm{~cm} / \mathrm{jam}$, dengan klasifikasi sebagai berikut:

1) nilai permeabilitas tanah sedang (jenis tanah lanau, 2,0 - 3,6 cm/jam atau 0,48 $-0,864$ $\mathrm{m}^{3} / \mathrm{m}^{2} /$ hari). 
2) nilai permeabilitas tanah agak cepat (jenis tanah pasir halus, 3,6 - $36 \mathrm{~cm} / \mathrm{jam}$ atau 0,864 $8,64 \mathrm{~m}^{3} / \mathrm{m}^{2} /$ hari).

3) nilai permeabilitas tanah cepat (jenis tanah pasir kasar, lebih besar $36 \mathrm{~cm} / \mathrm{jam}$ atau 8,64 $\mathrm{m}^{3} / \mathrm{m}^{2} /$ hari).

e. Periode ulang hujan yang digunakan untuk perencanaan 2 tahun sekali terlampaui;

f. Intensitas hujan ditentukan dengan analisis Intensity Duration Frequency (IDF) dari daerah lokasi pembangunan dengan durasi hujan 2 jam dan periode ulang 2 tahunan.

Adapun Persamaan untuk menghitung kedalaman sumur resapan adalah sebagai berikut:

$$
H=\frac{Q}{\omega \pi r K}
$$

dengan:

$H \quad$ : kedalaman sumur $(\mathrm{m})$

$r \quad$ : radius sumur $(\mathrm{m})$

$K \quad:$ koefisien permeabilitas tanah $(\mathrm{m} / \mathrm{jam})$

$Q \quad$ : debit banjir rancangan $\left(\mathrm{m}^{3} / \mathrm{jam}\right)$

$\omega \quad: 5$ untuk sumur kosong berdinding porus

Debit banjir rancangan dapat ditentukan dengan menggunakan metode rasional, yaitu:

$$
Q=C I A
$$

dengan:

C : koefisien pengaliran, diambil 0.95 untuk wilayah perumahan padat

I : intensitas hujan ( $\mathrm{mm} / \mathrm{jam})$

A : luas lahan tadah hujan $\left(\mathrm{m}^{2}\right)$

Intensitas hujan dihitunga dengan menggunakan Persamaan Mononobe sebagai berikut:

$$
I=\frac{R_{24}}{24}\left(\frac{24}{t}\right)^{2 / 3}
$$

dengan:

$R_{24}$ : hujan rancangan dengan kala ulang tertentu $(\mathrm{mm})$, dalam konteks ini diambil 2 tahun

$t \quad$ : durasi hujan (jam), ditetapkan selama 2 jam

Tahapan akhir dari kegiatan pembuatan prototipe sumur resapan adalah proses pemasangan sistem sumur resapan. Pemasangan sumur resapan dilakukan dengan cara penggalian manual (tenaga manusia), dimana dinding sumur merupakan beton fabrikasi (buis beton).

\section{HASIL DAN PEMBAHASAN}

\section{A. Sosialisasi}

Semua tahapan dalam program IbM "Sosialisasi dan Implementasi Prototipe Sumur Resapan Untuk Konservasi Air Kawasan Permukiman di Kota Pangkalpinang" telah dilakukan dengan baik. Pada tahapan sosialiasasi, perubahan bentuk dari Focus Group Discussion (FGD) menjadi penyebaran poster harus dilakukan, mengingat diterapkannya pembatasan sosial akibat Covid-19. Meskipun demikian, 
beberapa langkah pendahuluan, seperti komunikasi dengan ketua RT dan ketua Perumahan tetap dilakukan secara langsung dengan menerapkan protokol kesehatan. Poster sosialisasi didesain dengan konsep infografis dan sederhana, agar menarik dan mudah dipahami oleh semua kalangan masyarakat. Isi poster mencakup identitas penyelenggara, judul, konsep dasar hujan-aliran, ketersediaan dan kebutuhan air, dampak pembangunan perumahan, serta teknologi sumur resapan. Gambar 2 adalah desain poster untuk kegiatan sosialisasi.

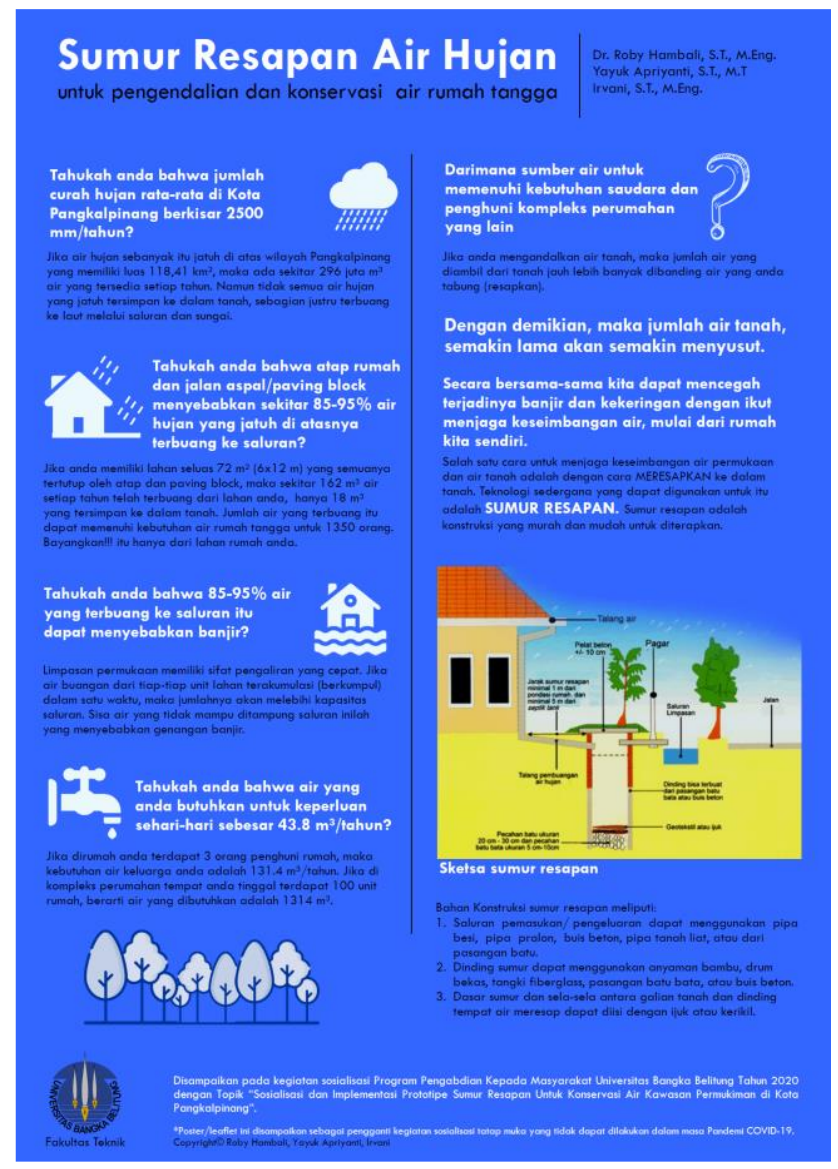

Gambar 2. Desain Poster

Penyebaran poster dilakukan door to door kepada warga penghuni perumahan dengan tetap memperhatikan protokol kesehatan (Gambar 3). Pada dasarnya, sistem sosialisasi seperti ini memiliki kelebihan dan kekurangan. Sosialisasi via poster memiliki kelebihan pada jumlah target jangkauan yang lebih besar dibanding FGD, namun kekurangannya adalah efektivitas ketersampaian informasi secara detail dan mendalam dimungkinkan masih rendah dibanding FGD. 


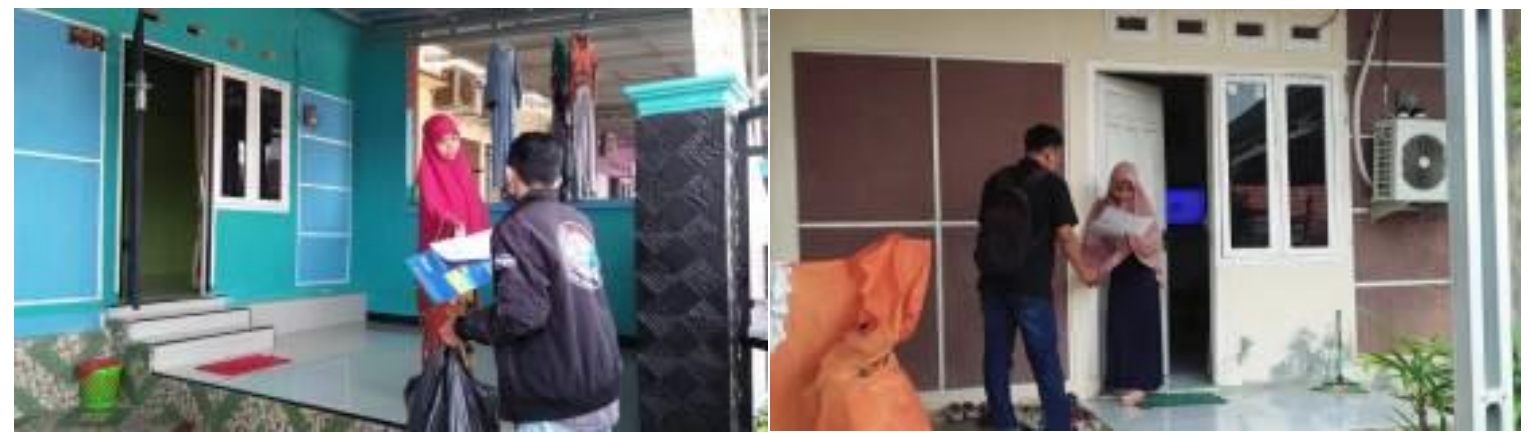

Gambar 3. Dokumentasi penyebaran poster door to door

Berdasarkan komunikasi dengan beberapa masyarakat di lokasi pengabdian, dapat diketahui bahwa secara umum masyarakat memiliki persepsi yang berbeda terhadap sumur resapan. Sebagian besar masyarakat beranggapan bahwa sumur reapan merupakan tampungan air untuk dapat dimanfaatkan, sementara pada kenyataannya sumur resapan merupakan sumur tampungan untuk diresapkan.

\section{B. Pengambilan dan Uji Sampel Tanah}

Sampel tanah yang diambil merupakan sampel tanah terganggu (disturbed sample). Pengambilan sampel dilakukan pada dua level kedalaman, yaitu kedalaman $1 \mathrm{~m}$ dan $2 \mathrm{~m}$. Hasil analisis saringan menunjukkan bahwa tanah pada kedua lokasi didominasi oleh tanah berpasir, dimana komposisi pasir halus berkisar $65.2 \%$, pasir sedang $18.9 \%$, dan pasir kasar $0.34 \%$. Gambar 4 merupakan foto pengambilan sampel di lapangan, sementara Gambar 5 merupakan grafik gradasi butir tanah hasil analisa saringan. Berdasarkan Unified Soil Clasification System (USCS), tanah dilokasi kegiatan diklasifikasikan sebagai tanah pasir berlempung dengan nilai koefisien permeabilitas berkisar 3.6-36 $\mathrm{cm} / \mathrm{jam}$.

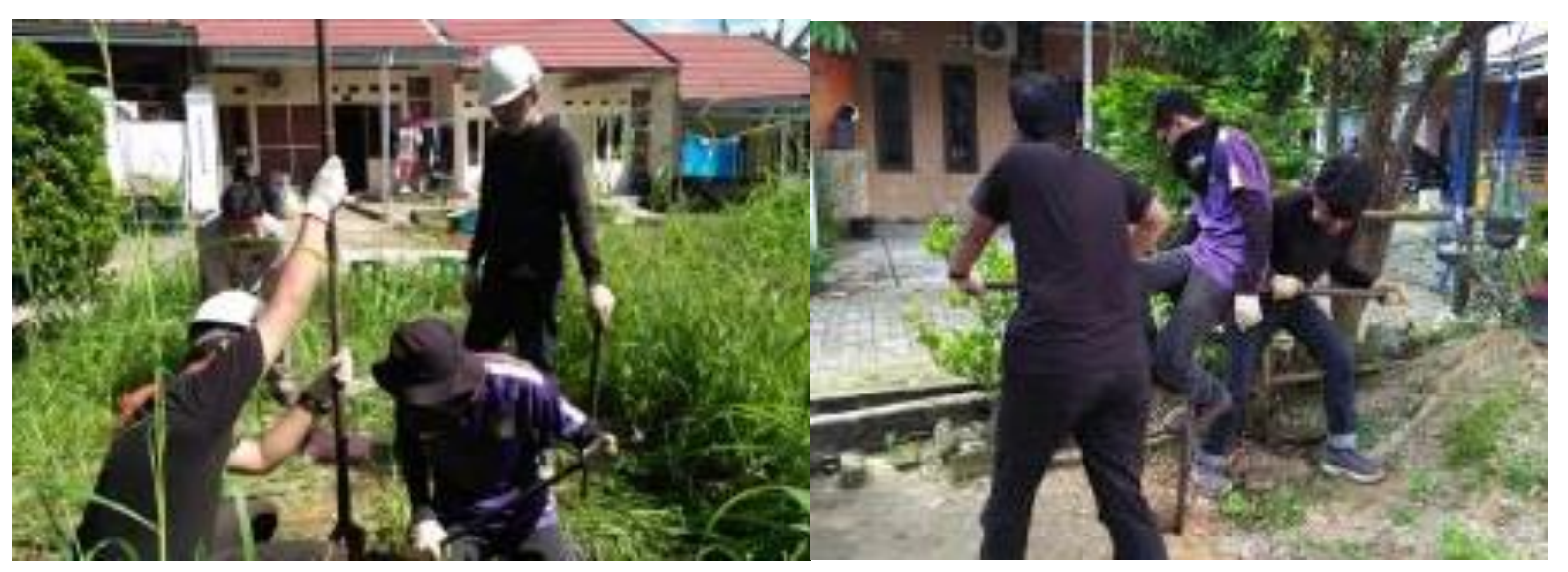

Gambar 4. Pengambilan sampel di lapangan 

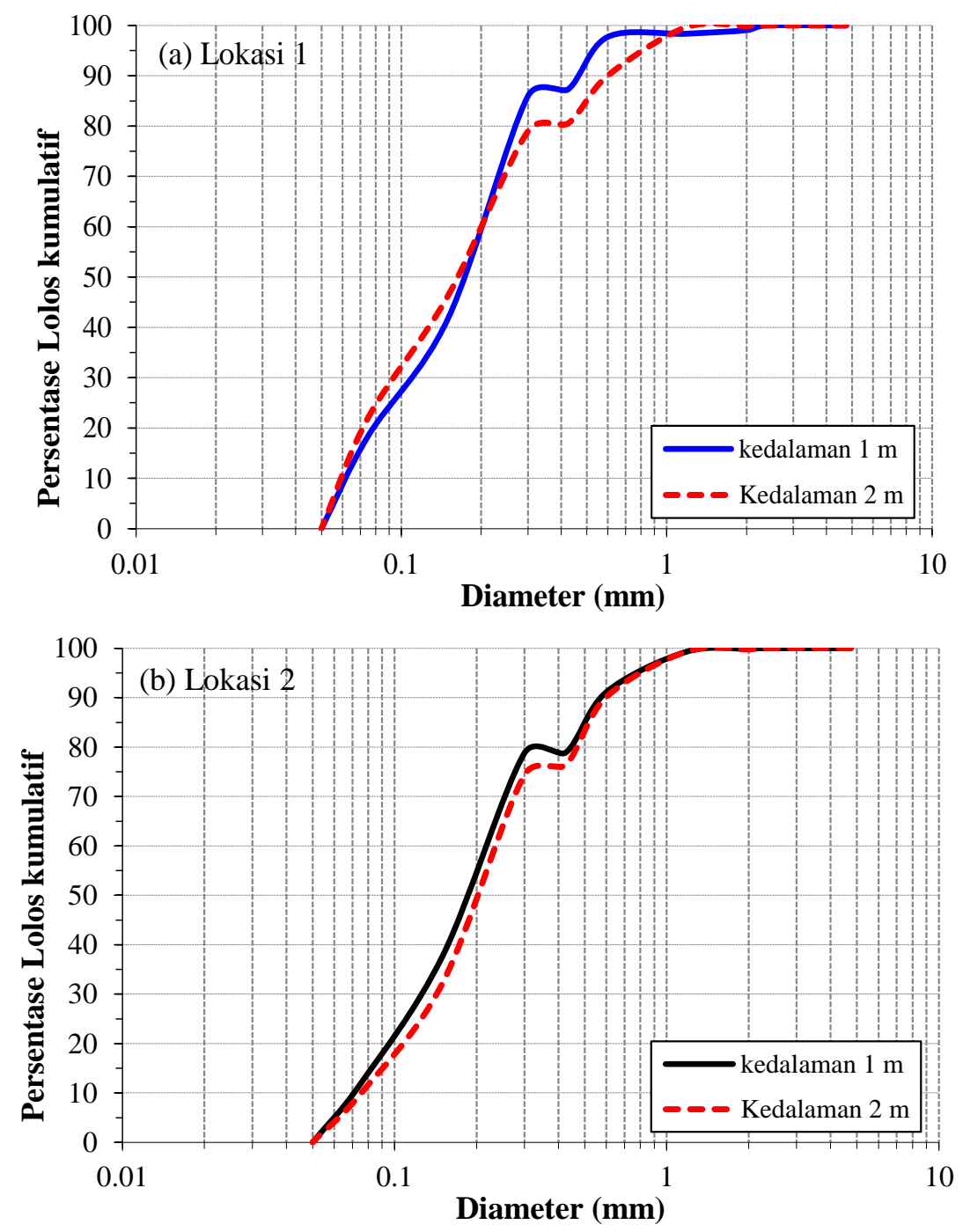

Gambar 5. Grafik gradasi butir tanah hasil analisa saringan

\section{Desain Prototipe Sumur Resapan}

Sebelum protipe sumur resapan diterapkan, analisis perhitungan kebutuhan dan kapasitas sumur resapan. Beberapa parameter rancangan perlu ditetapkan terlebih dahulu berdasarkan data skunder dan ketentuan (SNI 8456, 2017). Berdasarkan hasil analisis data hujan tahun 2002-2018, hujan rancangan $\left(R_{24}\right)$ di Kota Pangkalpinang mengikuti distribusi Normal. Besar curah hujan rancangan kala ulang 2 tahun sebesar $98.56 \mathrm{~mm}$. Dengan asumsi durasi $(t)=2$ jam, maka intensitas hujan rancangan $(I)$ adalah sebesar $16.43 \mathrm{~mm} / \mathrm{jam}$. Dengan asumsi rata-rata luas atap $(A)$ tiap unit lahan sebesar $80 \mathrm{~m}^{2}$ dan koefisien pengaliran $(C)=0.95$, maka debit limpasan $(Q)$ adalah sebesar $1.31 \mathrm{~m}^{3} / \mathrm{jam}$. Kedalaman sumur resapan dihitung menggunakan Persamaan (1). Tanah di lokasi perumahan merupakan tanah pasir berlempung $(S C)$. Koefisien permeabilitas $(K)$ ditetapkan sebesar $16 \mathrm{~cm} / \mathrm{jam}$ untuk kategori sedang. Jika dipilih buis beton dengan diameter $80 \mathrm{~cm}$, maka kedalaman sumur resapan yang dibutuhkan untuk 1 (satu) unit lahan adalah $2 \mathrm{~m}$. Perhitungan kebutuhan sumur resapan sebagai berikut: 


$$
\begin{aligned}
& H=\frac{Q}{\omega \pi r K} \\
& H=\frac{1.31}{3.5 \times \pi \times 0.8 \times 0.16}=2.03 \mathrm{~m}
\end{aligned}
$$

Nilai $\omega$ ditetapkan sebesar 3.5 karena dinding sumur tidak sepenuhnya porus. Kedalaman sumur yang dibutuhkan adalah $2.03 \mathrm{~m} \approx 2 \mathrm{~m}$. Oleh karena masing-masing buis beton dicetak dengan ketinggian $40 \mathrm{~cm}$, maka kebutuhan buis beton adalah 5 (lima) buah untuk tiap-tiap sumur. Sketsa desain sumur resapan disajikan pada Gambar 6.

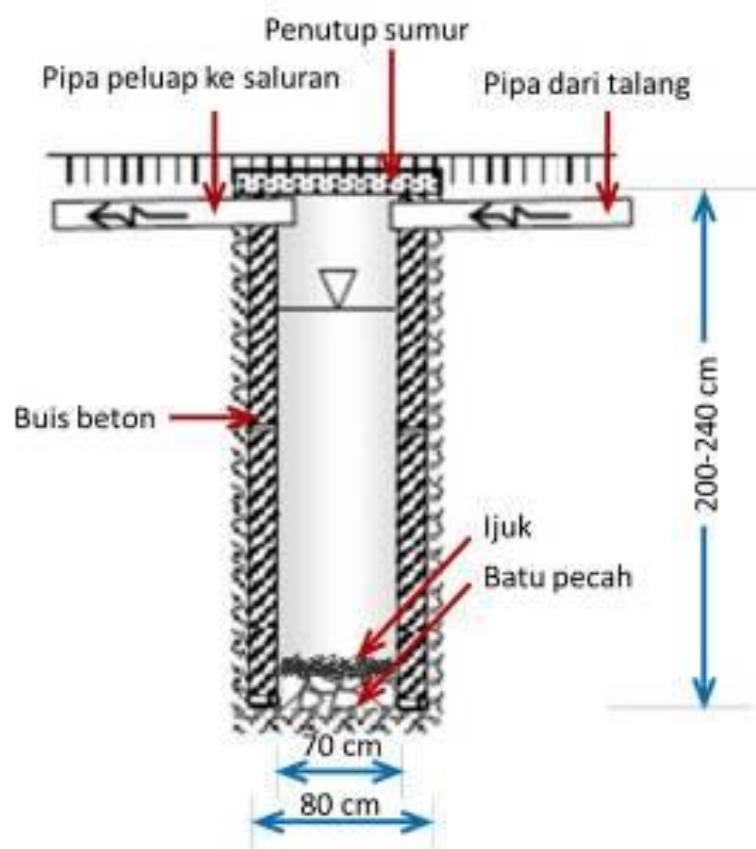

Gambar 6. Desain sumur resapan

\section{Pemasangan Sistem Sumur Resapan}

Pemasangan prototipe sumur resapan dilakukan pada dua lokasi, dimana pada Perumahan Indo Griya sebanyak 3 sumur, sementara pada Indo Residence sebanyak 1 sumur. Penentuan jumlah sumur tersebut didasarkan pada ketersediaan lahan untuk pemasangan. Pada daerah Perumahan Indo Griya, lahan yang digunakan untuk sumur resapan adalah ruang terbuka hijau milik Perumahan, sementara di Indo Residence, lahan yang digunakan adalah halaman rumah warga. Koordinasi intensif bersama penanggungjawab perumahan ataupun tokoh representatif sangat diperlukan, mengingat status penggunaan lahan publik di perumahan yang tidak terarah. Penggunaan halaman rumah warga didasarkan pada permintaan warga sendiri. Gambar 7 adalah dokumentasi pelaksanaan pemasangan prototipe sumur resapan. 

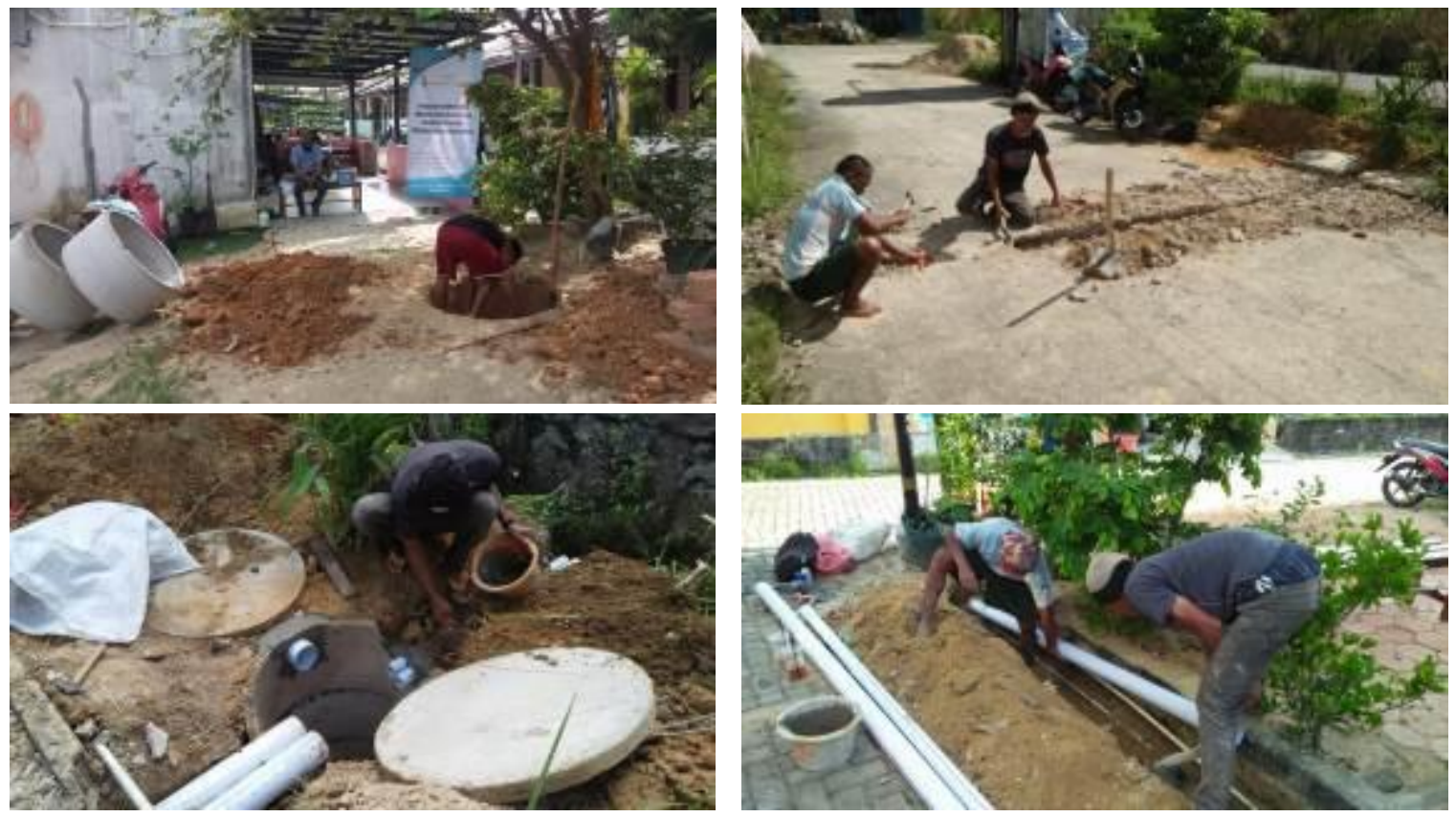

Gambar 7. Pelaksanaan pemasangan prototipe sumur resapan

Prototipe sistem sumur resapan yang dipasang terdiri dari unit galian sumur dan pasangan buis beton ukuran $70 \mathrm{~cm}$, pipa inlet diameter 4", pipa outlet diameter 2.5", tutup sumur dari cor beton, serta talang pipa diameter 3 ". Proses pemasangan dilakukan secara bertahap, mulai dari penggalian lubang sumur, pemasangan dinding sumur, Pemasangan lapis dasar (filter), pemasangan talang air hujan dan pipa, serta perapian kembali daerah sekitar galian sumur.

Penggalian sumur dilakukan secara manual menggunakan tenaga manusia. Kecepatan penggalian sangat tergantung pada struktur tanah di lokasi pemasangan. Meskipun tanah didominasi oleh pasir, namun pada sebagian lubang galian juga terdapat tanah keras. Jika dilakukan oleh satu orang tukang gali, maka waktu penggalian dapat mencapai 7 (tujuh) jam. Pemasangan dan pengaturan presisi buis beton memakan waktu tidak lebih dari 1 jam. Pemasangan pipa inlet, outlet dan talang dapat diselesaikan dalam waktu 9 (sembilan) jam oleh 3 (tiga) orang tukang. Total waktu yang dibutuhkan untuk seluruh proses pemasangan sistem sumur resapan adalah 4 (empat) hari ( \pm 30 jam).

Secara teknis, tidak ada kendala dalam pemasangan prototipe sistem sumur resapan, baik material maupun metode pemasangannya. Persoalan utama yang ditemui di lapangan adalah kesulitan mencari lahan untuk pemasangan sumur resapan. Secara umum, ruang terbuka hijau milik umum (warga perumahan) yang tersedia sangat sedikit. Sebagian dari ruang publik yang ada bahkan telah dijual oleh pengembang untuk dibangun rumah, sebagian lagi menjadi perubutan warga perumahan untuk dijadikan hak miliki. Disisi lain, cukup sulit untuk mengukur tingkat partisipasi masyarakat dalam implementasi kegiatan IbM di masa pandemi Covid-19. Sebagian besar masyarakat tidak ingin terlibat langsung, karena masih teguh menerapkan physical distancing, sementara sebagian lainnya hanya terlibat secara tidak langsung melalui kesediannya terhadap penggunaan atap rumah mereka sebagai sumber air buangan.

Meskipun sumur resapan sudah terpasang dengan baik, pemeriksaan berkala perlu dilakukan untuk menjamin kontinuitas operasi sumur resapan. Pemeriksaan berkala dapat dilakukan setiap 6 (enam) bulan sekali oleh warga perumahan yang meliputi aliran masuk, aliran keluar, kondisi sumur resapan. 


\section{KESIMPULAN DAN SARAN}

Pembangunan prototipe sumur resapan di kawasan perumahan padat penduduk Kota Pangkalpinang merupakan bagian dari sosialisasi implementasi metode konservasi air pada tingkat rumah tangga perkotaan. Melalui kegiatan yang telah dilakukan, capaian kegiatan dapat disimpulkan sebagai berikut:

(1) Meningkatnya pengetahuan sebagian masyarakat tentang konsep tata kelola air hujan berwawasan lingkungan pada level rumah tangga, khususnya warga perumahan Indo Griya dan Indo Residence.

(2) Terbangunnya prototipe sumur resapan air hujan sebagai contoh implementasi teknologi konservasi air pada level rumah tangga.

(3) Belum tercapainya partisipasi aktif masyarakat dalam implementasi teknologi konservasi air, mengingat adanya pembatasan fisik dalam situasi pandemi Covid-19.

Terbatasnya koordinasi ke kelompok warga representatif di lingkungan perumahan dalam masa pendemi Covid-19 merupakan kendala utama yang menghambat kelancaran pembuatan sumur resapan. Pertemuan langsung dalam forum diskusi warga merupakan faktor penting keberhasilan secara menyeluruh kegiatan IbM, karena berkaitan dengan penggunaan ruang publik. Untuk meningkatkan partisipasi masyarakat dalam era kelaziman baru (new normal), diperlukan gagasan yang lebih efektif dalam hal pendekatan ke masyarakat, sehingga masyarakat dapat terlibat langsung, mulai dari perencanaan hingga pemeliharaan sumur resapan.

\section{UCAPAN TERIMA KASIH}

Penulis mengucapkan terima kasih kepada LPPM Universitas Bangka Belitung atas pembiayaan kegiatan ini melalui skema PMTU tahun 2020. Penulis juga mengucapkan terima kasih kepada pejabat kelurahan Selindung dan Jerambah Gantung, serta warga Perumahan Indo Griya dan Indo Residen Kota Pangkalpinang atas kerjasamanya menjadi mitra Pengabdian Universitas Bangka Belitung.

\section{DAFTAR PUSTAKA}

Anonim. (2020). Sistem Informasi Perumahan dan Permukiman Kota Pangkalpinang. Disperkim Kota Pangkalpinang. https://disperkim.pangkalpinangkota.go.id/sipp/.

Azis, A., Yusuf, H., \& Faisal, Z. (2016). Konservasi Air Tanah Melalui Pembuatan Sumur Resapan Air Hujan di Kelurahan Maradekaya Kota Makassar. Journal INTEK, 3(2), 87.

Bunganaen, W., Sir, T. M. W., \& Penna, C. (2016). Pemanfaatan Sumur Resapan Untuk Meminimalisir Genangan di Sekitar Jalan Cak Doko. Jurnal Teknik Sipil, 1, 67.

Fachrurazie, C., Arifin, Y. F., \& Susanti, D. S. (2002). Analisa Drainase Sumur Resapan Pada Kampus UNLAM Banjarbaru. Info-Teknik, 3(1), 24.

Ferdiansyah, R. (2019). Lebih Dari Satu Juta Warga Babel Terdampak Kekeringan. Media Indonesia. https://mediaindonesia.com/

Hambali, R. (2020). Tanpa RTH yang Cukup, Pembangunan Perumahan Jadi Ancaman Kelestarian Sumber Daya Air. Media Bangka Belitung. https://lensabangkabelitung.com

Maria, R., \& Lestiana, H. (2014). Pengaruh Penggunaan Lahan Terhadap Fungsi Konservasi Air Tanah di 
Sub DAS Cikapundung. Riset, 24(2), 77.

SNI 1966. (2008). Standar Nasional Indonesia (SNI) 1966-2008, Cara Uji Penentuan Batas Plastis dan Indeks Plastisitas Tanah. Jakarta : Badan Standardisasi Nasional.

SNI 1967. (2008). Standar Nasional Indonesia (SNI) 1967-2008, Cara Uji Penentuan Batas Cair Tanah. Jakarta : Badan Standardisasi Nasional.

SNI 3423. (2008). Standar Nasional Indonesia (SNI) 3423-2008, Cara Uji Analisis Ukuran Butiran Tanah. Jakarta : Badan Standardisasi Nasional.

SNI 8456. (2017). Standar Nasional Indonesia (SNI) 8456:2017, Sumur dan Parit Resapan Air Hujan. Jakarta : Badan Standardisasi Nasional. 